\title{
Feasibility of the Routine Clinical Use of a Multiplex Virus Polymerase Chain Reaction Assay Based on Blood Virus Detection in Hematopoietic Stem Cell-Transplanted Patients
}

\author{
Hiroko Tsunemine1, Miho Sasaki², Yuriko Zushi'2, Toshiharu Saitoh², Norio Shimizu3 \\ Yasuhiro Tomaru ${ }^{3}$, Yumi Aoyama1, Ryusuke Yamamoto', Tomomi Sakai', \\ Nobuyoshi Arima1, Taiichi Kodaka1, Takayuki Takahashi1,4* \\ ${ }^{1}$ Departments of Hematology, Shinko Hospital, Kobe, Japan \\ ${ }^{2}$ Cell Therapy, Shinko Hospital, Kobe, Japan \\ ${ }^{3}$ Center for Stem Cell and Regenerative Medicine, Tokyo Medical and Dental University, Tokyo, Japan \\ ${ }^{4}$ Akasaka Hematology \& Oncology Clinic, Kobe, Japan \\ Email: ^takahashi.takayuki@shinkohp.or.jp
}

How to cite this paper: Tsunemine, H., Sasaki, M., Zushi, Y., Saitoh, T., Shimizu, N., Tomaru, Y., Aoyama, Y., Yamamoto, R., Sakai, T., Arima, N., Kodaka, T. and Takahashi, T. (2022) Feasibility of the Routine Clinical Use of a Multiplex Virus Polymerase Chain Reaction Assay Based on Blood Virus Detection in Hematopoietic Stem Cell-Transplanted Patients. International Journal of Clinical Medicine, 13, 67-81

https://doi.org/10.4236/ijcm.2022.132006

Received: January 10, 2022

Accepted: February 20, 2022

Published: February 23, 2022

Copyright $\odot 2022$ by author(s) and Scientific Research Publishing Inc. This work is licensed under the Creative Commons Attribution International License (CC BY 4.0).

http://creativecommons.org/licenses/by/4.0/

(c) (i) Open Access

\begin{abstract}
Background: Multiplex virus assays are useful in immunocompromised hosts but still challenging in routine clinical settings in terms of their sensitivity, specificity, reproducibility, and time and cost performances. In recent years, we developed a qualitative multiplex virus PCR assay capable of the simultaneous detection of 13 virus species within $3 \mathrm{~h}$. However, because of the multiple and concomitant nature of this virus assay, it should be validated for qualitative reliability. Materials and Methods: As a preclinical examination, this multiplex PCR was able to detect $1.25 \times 10^{3}$ copies $/ \mathrm{mL}$ of 13 synthesized virus genomes and preserved same virus DNAs by the serial dilution method. Blood samples from 40 patients who underwent hematopoietic stem cell transplantation were then examined by multiplex PCR for 13 virus species, followed by quantitative real-time PCR for all 13 virus species as reference PCR when these patients developed symptoms suggestive of viral infection. Results: In 421 cumulative qualitative-quantitative tests, the multiplex PCR certainly detected $1.0 \times 10^{3}$ copies/mL of 5 viruses (CMV, JCV, BKV, HHV-6, $\mathrm{ADV}$ ) that were frequently detected and thus reasonably analyzed. The positive and negative predictive values of multiplex PCR were $84.2 \%-93.3 \%$ and $90.7 \%-99.0 \%$, respectively, and sensitivity and specificity were $59.0 \%-83.3 \%$ and $97.2 \%-99.2 \%$, respectively, for these 5 viruses. Conclusion: From these performances, the multiplex PCR assay may be acceptable in a routine clinical laboratory setting.
\end{abstract}




\section{Keywords}

Multiplex Virus PCR Assay, Routine Laboratory Use, Positive Predictive Value, Negative Predictive Value, Sensitivity, Specificity

\section{Introduction}

Virus assays are indispensable in immunocompromised hosts but still challenging to perform in routine clinical settings in terms of their sensitivity, specificity, reproducibility, and time and cost performances. In the early era of laboratory medicine, a serological virus assay was typically employed, capable of detecting just a single virus type with a poor time performance [1] [2], although the serological assay is still useful to determine a viral infection as the first, past infections, or re-activation. About three decades ago, virus polymerase chain reaction (PCR) assays were introduced [3] [4] [5] [6] [7], although they were still single-virus assays. However, majority of these studies are remaining as the reference in terms of sensitivity and specificity for respective viruses. In recent years, a number of multiplex virus PCR assays have been developed [8]-[13]; however, these assays have mainly been used for research, not as routine clinical tests, and the number and kind of assayable viruses differ from those of our own assay (13 virus species). In addition, Hwang et al. developed a refined multiplex real-time PCR assay in recent years, although assayable viruses were 3 kinds [14].

About 10 years ago, we developed a multiplex qualitative virus PCR assay targeting 12 representative virus species which affect immunocompromised patients, and used it in several clinical studies, including for assessing liver dysfunction [15], hematopoietic stem cell transplantation (HSCT) and miscellaneous immunodeficiency [16], infectious mononucleosis [17], and gastrointestinal virus infection [18]. Through these studies, we observed that this multiplex PCR assay was useful in terms of its sensitivity, specificity, ability for multiple and simultaneous virus detection, and rapid performance. In particular, we considered this virus assay to be indispensable for making an early diagnosis of virus infection or viremia in patients with a history of HSCT, regardless of the setting of a clinical study. For example, we could save a few patients' lives with our multiplex PCR making early diagnoses of life-threatening viral infection such as disseminated visceral varicella-zoster virus infection, meningitis by herpes simplex type $1 / 2$, encephalitis by human herpes virus type 6 , colitis by cytomegalovirus, and reactivation of human hepatitis B virus [16]. In addition, a group of Japanese investigators reported viral reactivation after HSCT in a large patient cohort as a clinical study using a multiplex PCR assay system that was basically the same as ours [19].

We therefore proposed the possibility of the routine clinical use of this multiplex virus PCR assay. In the present study, we validated our virus PCR assay for routine clinical use based on virus detection in patients who underwent HSCT in 
our institution.

\section{Materials and Methods}

\subsection{Patients}

All patients who received HSCT from May 2015 to July 2021 in Shinko Hospital were included in the present study. A total 40 patients received HSCT, including 24 and 16 allogeneic and autologous transplantations, respectively. The median age of 40 patients was 58 years old (range: 48 - 69 years old), of which 21 and 19 patients were male and female, respectively. The conditioning regimen for allogeneic transplantation was standard fludarabine +4 -day busulfan (Ful-Bu4), cyclophosphamide + total body irradiation, or Ful-Bu $4+$ melphalan. The conditioning regimens for autologous transplantation for malignant lymphoma and multiple myeloma were ranimustine + etoposide + cytarabine + melphalan (MEAM) and high-dose melphalan, respectively.

\subsection{Ethical Statement}

The present prospective analysis was a single-institutional clinical study, designated, "The early diagnosis of viral infection by multiplex virus PCR assay in hematopoietic stem cell-transplanted patients", which had been approved by the institutional review board in June 2015 (IRB No.: 1505).

\subsection{Blood Samples}

EDTA-2Na-chelated whole blood $(2 \mathrm{~mL})$ was obtained before and after HSCT after obtaining written informed consent from each patient. After HSCT, the blood sample was collected when individual patients developed symptoms or clinical findings suggestive of viral infection, such as a fever, dyspnea, skin rash, headache, abdominal pain, diarrhea, or a high C-reactive protein (CRP) level. In the present study, individual patients developed multiple such episodes after HSCT. Accordingly, a median of 9.0 (range 4 - 27) multiplex virus PCR assays combined with real-time virus PCR assays were performed per patient.

\subsection{Multiplex Qualitative Virus PCR and Quantitative Real-Time PCR Assay}

After obtaining the blood sample, we collected the plasma and then extracted DNA using the QIamp MinElute Virus Spin kit (Qiagen, Tokyo, Japan). In this procedure, we obtained $100 \mu \mathrm{L}$ of DNA solution (BufferAVE) (Qiagen) from 400 $\mu \mathrm{L}$ plasma. Although the methods of the multiplex virus PCR and real-time PCR assays were previously described in detail [15] [16], including the primer and probe sequences for 13 virus species, we modified a few points in the present study.

First, we performed a multiplex virus PCR assay using the GVP-9600 Gene Detection System (Shimadzu Corporation, Kyoto, Japan) and a solid-phase plate consisting of seven-well plates (Opportunistic DNA Viruses Detection Kit) (Shimadzu), in which primers, probes, Taq, and buffer constituents were fixed in 
advance as a solid phase on well plates. Each well is for 2 or 3 kinds of virus species and for TBP and GADPH. The probes in the corresponding wells were labeled with 3 kinds of fluorochromes, 6FAM TM, HEX TM, and ROX TM [16]. We purchased the Viruses Detection Kit from Shimadzu Corporation. Second, we added $10 \mu \mathrm{L}$ DNA solution instead of the previously mentioned $2 \mu \mathrm{L}$ to the reaction mixture for the multiplex qualitative PCR assay in the present study. Therefore, the reaction mixture at a final volume was $20 \mu \mathrm{L}$ consisted of $10 \mu \mathrm{L}$ DNA solution and $10 \mu \mathrm{L} \mathrm{dH}_{2} \mathrm{O}$. Third, we performed quantitative real-time PCR for all 13 virus species after a qualitative multiplex PCR assay, regardless of the virus detection by multiplex PCR, to validate the accuracy of the multiplex PCR assay using the GVP-9600 Gene Detection System (Shimadzu). Namely, we designated this multiplex PCR followed by real-time PCR for all 13 virus species as one test per blood sample. The lower detection limit of our real-time PCR for 13 virus species was $2.5 \times 10^{2}$ copies $/ \mathrm{mL}$.

The 13 virus species examined in the present study were as follows: cytomegalovirus (CMV), JC virus (JCV), BK virus (BKV), human herpes virus type 6 (HHV-6), adenovirus (ADV), Epstein-Barr virus (EBV), parvovirus B19 (ParvoB19), varicella-zoster virus (VZV), human hepatitis B virus (HBV), herpes simplex virus type 1 (HSV-1), HSV-2, HHV-7, and HHV-8. Namely, ADV was an additional target in the multiplex PCR employed in the present study, differing from previous assay system targeting 12 virus species [15] [16] [17] [18].

Real-time PCR for CMV targeted the UL 83 gene domain [20]. Regarding CMV WHO International Standard [7] [21], the value obtained with our real-time PCR can be converted to the Standard value by multiplying by 0.3 . This conversion was based on the comparison of the quantification cycle $(\mathrm{Cq})$ value between the Standard system and our real-time PCR, that is, Cq values for $1000 \mathrm{IU}$ of International standard (NIBSC code: 09/162) and our standard of 1000 copy/mL were $30.24(\mathrm{n}=3)$ and $28.50(\mathrm{n}=3)$, respectively (unpublished data). Regarding HHV-6, our multiplex-real time PCR system detected both the HHV-6A and HHV-6B genomes.

\subsection{Detection Performance of the Multiplex PCR Assay by Serial Dilution of Virus DNA}

The detection performance of multiplex PCR was examined by serial dilution of plasmid DNA for 13 virus species, which were synthesized by Nihon Techno Service Company (Ibaraki, Japan), and preserved DNA for 13 virus species from patients in whom the respective virus genomes had been detected and quantified with real-time PCR in the present study or the previous clinical study ("Multiple Virus-Analytic Study by Multiplex PCR"), which had been approved by the institutional review board in December 2010 (IRB No.: 0939). Our previous studies [15] [16] [17] [18] were performed under this approval. The detection performance test using preserved DNA from blood samples was also approved by the institutional review board (December 2018; IRB No.: 1834), and we provided patients with an opportunity to opt out from this analysis. 


\subsection{Statistical Analyses}

The positive predictive value (PPV), negative predictive value (NPV), sensitivity, and specificity of multiplex qualitative PCR were calculated according to conventional formulas using a calculator. To compare the mean values, student's $t$-test was used.

\section{Results}

\subsection{Detection Performance of the Qualitative Multiplex PCR Assay Examined with Virus Genomes and Preserved Virus DNA}

As a preclinical study, we first examined the detection performance of qualitative multiplex PCR with a known copy number of viruses by serial dilution. The detection performance was examined 2 ways: using synthesized plasmid DNA for 13 respective virus genomes and using preserved DNA from patients previously examined for viremia. With synthesized plasmid DNA, we performed 12-time repeated experiments with an almost $100 \%$ yield of positive detection of all 13 virus species at the lowest DNA concentration of $1.25 \times 10^{3}$ copies $/ \mathrm{mL}$ as well as at higher concentrations (Table 1). With preserved DNA, we performed

Table 1. Detection performance of multiplex virus PCR assays for 13 virus species by serial dilution of synthesized plasmid DNA for respective virus genomes and preserved DNA from patients previously examined.

\begin{tabular}{ccc}
\hline Viruses & $1.25 \times 10^{4}$ and $6.25 \times 10^{3}$ copies $/ \mathrm{mL}$ & $1.25 \times 10^{3}$ copies $/ \mathrm{mL}$ \\
\hline CMV & $12 / 12(5 / 5)$ & $12 / 12(5 / 5)$ \\
JCV & $12 / 12(5 / 5)$ & $12 / 12(5 / 5)$ \\
BKV & $12 / 12(5 / 5)$ & $11 / 12(4 / 5)$ \\
HHV-6 & $12 / 12(5 / 5)$ & $12 / 12(5 / 5)$ \\
ADV & $12 / 12(5 / 5)$ & $11 / 12(5 / 5)$ \\
EBV & $12 / 12(5 / 5)$ & $12 / 12(5 / 5)$ \\
ParvoB19 & $12 / 12(5 / 5)$ & $12 / 12(5 / 5)$ \\
VZV & $12 / 12(5 / 5)$ & $11 / 12(4 / 5)$ \\
HBV & $12 / 12(5 / 5)$ & $12 / 12(4 / 5)$ \\
HSV-1 & $12 / 12(5 / 5)$ & $11 / 12(5 / 5)$ \\
HSV-2 & $12 / 12(5 / 5)$ & $11 / 12(3 / 5)$ \\
HHV-7 & $12 / 12(5 / 5)$ & $12 / 12(\mathrm{ND}: \mathrm{DNA}$ not available) \\
HHV-8 & $12 / 12(5 / 5)$ &
\end{tabular}

Each data point indicates number of positive virus detection per 12 and 5 repeated experiments. The data in the parenthesis indicate the results of experiments using preserved DNA. ND: not done. CMV: cytomegalovirus, JCV: JC virus, BKV: BK virus, HHV-6/7/8: human herpes virus type-6/7/8, ADV: adenovirus, EBV: Epstein-Barr virus, ParvoB19: parvovirus B19, VZV: varicella-zoster virus, HBV: human hepatitis B virus, HSV-1/2: herpes simplex virus type-1/2. 
5-time repeated experiments with similar results at DNA concentrations of 1.25 $\times 10^{3}$ copies/mL as with synthesized plasmid DNA (Table 1 ). We performed 5 -time repeated experiments but not more repeating with preserved DNA because of limited amounts of the DNA.

\subsection{Number of Virus PCR Tests and Incidence of Virus Detection in Patients Who Received HSCT}

Synthesized plasmid DNA samples have few contaminants, such as protein, which may interfere with PCR. In the detection performance test using preserved DNA, the concentration of contaminants in the sample may have been reduced by serial dilution. Therefore, we examined the performance of our multiplex PCR assay using clinical specimens.

As shown in Table 2, a total of 40 patients received allogeneic $(n=24)$ or autologous $(n=16)$ HSCT. The virus test (multiplex PCR followed by real-time PCR for 13 virus species) was performed until episodes suggestive of viral infection disappeared in patients after HSCT. However, in four patients who received allogeneic HSCT, the disappearance of the suggestive episode could not be confirmed because of early death due to engraftment failure (one patient) or recurrence of underlying neoplasm (three patients). As a result, the median number of tests per patient was 9.0, resulting in a total of 421 tests being performed, including those before HSCT, in all 40 patients. The number of tests per patient in allogeneic HSCT $(11.0)$ was significantly higher $(\mathrm{P}<0.01)$ than that in autologous HSCT (7.0). However, the incidence of virus detection in cumulative tests by real-time PCR (at least one virus detection) and the number of virus species per

Table 2. Number of virus PCR test and virus detection in patients who received HSCT.

\begin{tabular}{|c|c|c|c|}
\hline & $\begin{array}{l}\text { Total HSCT } \\
\quad(n=40)\end{array}$ & $\begin{array}{l}\text { Allogeneic HSCT } \\
\qquad(n=24)\end{array}$ & $\begin{array}{l}\text { Autologous HSCT } \\
\qquad(\mathrm{n}=16)\end{array}$ \\
\hline $\begin{array}{l}\text { Cumulative No. of } \\
\text { virus PCR test }\end{array}$ & 421 & 301 & 120 \\
\hline $\begin{array}{l}\text { No. of virus } \\
\text { test/patient }\end{array}$ & $\begin{array}{l}\text { Median: } 9.0 \\
\text { (range: } 4 \text { - 27) }\end{array}$ & $\begin{array}{l}\text { Median: } 11.0^{*} \\
\text { (range: } 4-27 \text { ) }\end{array}$ & $\begin{array}{l}\text { Median: } 7.0 \\
\text { (range: } 4-14 \text { ) }\end{array}$ \\
\hline $\begin{array}{l}\text { Incidence of virus } \\
\text { detection }\end{array}$ & $56.5 \% / 421$ tests & $56.5 \% / 301$ tests & $56.7 \% / 120$ tests \\
\hline $\begin{array}{l}\text { Patients with virus } \\
\text { detection }\end{array}$ & $39 / 40(97.5 \%)$ & $24 / 24(100.0 \%)$ & $15 / 16(93.8 \%)$ \\
\hline $\begin{array}{c}\text { No. of virus } \\
\text { species detected }\end{array}$ & $\begin{array}{l}\text { Median: } 3.0 \\
\text { (range: } 0-6 \text { ) }\end{array}$ & $\begin{array}{l}\text { Median: } 3.0 \\
\text { (range: } 1-5 \text { ) }\end{array}$ & $\begin{array}{l}\text { Median: } 2.0 \\
\text { (range } 0-6 \text { ) }\end{array}$ \\
\hline $\begin{array}{l}\text { No. of patient with positive } \\
\text { test before HSCT }\end{array}$ & $\begin{array}{c}11 \\
(\mathrm{CMV}, \mathrm{HHV}-6, \\
\mathrm{JCV}, \mathrm{BKV}, \mathrm{EBV})\end{array}$ & $\begin{array}{c}6 \\
(\mathrm{CMV}, \mathrm{HHV}-6, \\
\mathrm{JCV}, \mathrm{BKV}, \mathrm{EBV})\end{array}$ & $\begin{array}{c}5 \\
(\mathrm{CMV}, \mathrm{BKV}, \mathrm{JCV})\end{array}$ \\
\hline
\end{tabular}

One virus PCR test means multiplex PCR for 13 virus species followed by real-time PCR for all 13 virus species. HSCT: Hematopoietic stem cell transplantation. ${ }^{*}: \mathrm{P}<0.01$ when compared with test number in autologous HSCT. 
patient were not significantly different between allogeneic and autologous HSCT (Table 2). In 11 patients, one or 2 virus species were detected at low copy numbers before HSCT. We showed a representative time course of virus detection in Figure 1 in a patient in whom 4 virus species were detected.

\subsection{Detection of 13 Virus Species by Real-Time PCR in Patients Who Received HSCT}

Regarding positive tests on real-time PCR, the most frequently detected virus was CMV (33.3\%), followed by BKV (15.7\%), JCV (14.5\%), HHV-6 (10.2\%), EBV (6.4\%), ADV (4.8\%), ParvoB19 (1.7\%), VZV (0.5\%), and HBV (0.5\%) among 421 cumulative tests. HSV-1/2 and HHV-7/8 were not detected in this study. Although the pattern of virus detection was similar between allogeneic and autologous HSCT, ADV was detected only in one test in an autologous HSCT patient. Symptomatic virus disease was observed only in one allo-transplanted patient who developed ADV cystitis with a favorable outcome.

\subsection{Relationship between Positivity by Real-Time PCR and Multiplex Qualitative PCR}

As shown in Figure 2, we plotted all real-time PCR positive results alongside the results of qualitative multiplex PCR (qual), showing the copy number of viruses and virus species on the vertical and horizontal axes, respectively. The presence of two horizontal plots means a true positive test (i.e. a positive test), while only one real-time PCR-positive plot in red color means a false negative multiplex PCR test at the indicated copy number. Because real-time PCR detects viruses even at low copy numbers, we examined the virus copy number at which false negative multiplex PCR test results would be obtained. Many false negative tests were observed below copy numbers of $1 \times 10^{2} / \mathrm{mL}$, but small number between $1 \times$ $10^{2} / \mathrm{mL}$ and $1 \times 10^{3} / \mathrm{mL}$, and none above $1 \times 10^{3} / \mathrm{mL}$ except for 2 tests in HHV-6

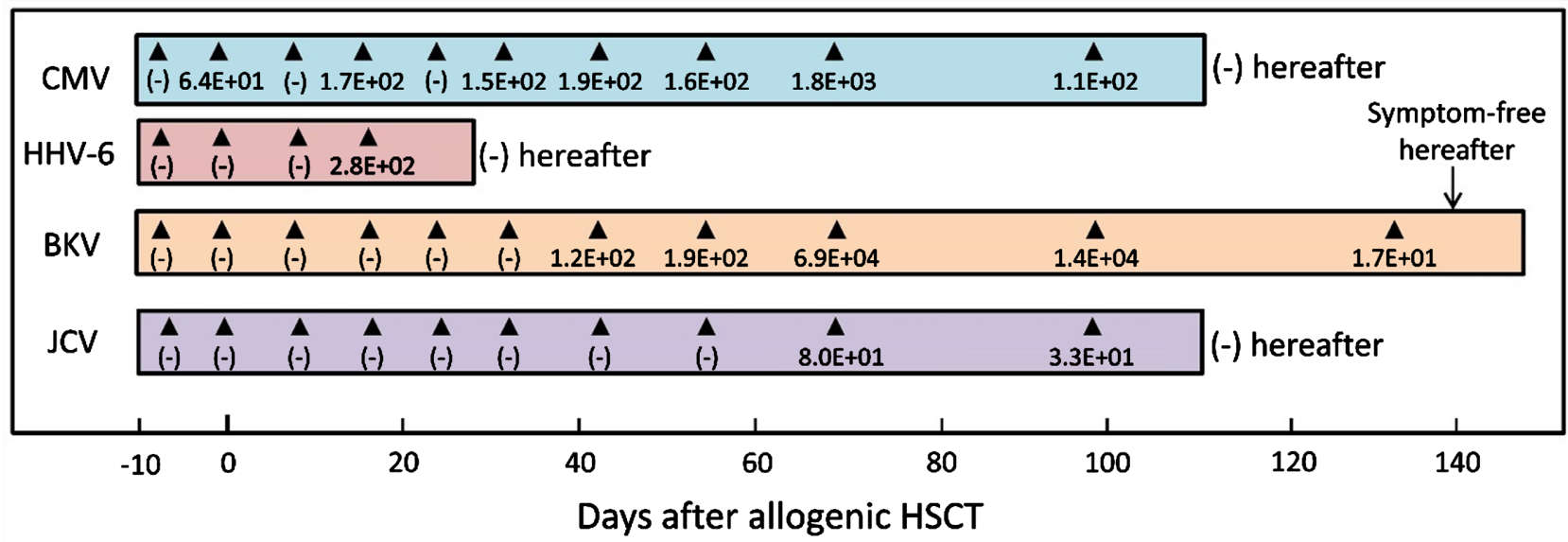

(-): no virus detection, HSCT: hematopoietic stem cell transplantation. CMV: cytomegalovirus, HHV-6: human herpes virus type-6, BKV: BK virus, JCV: JC virus.

Figure 1. A representative time course of virus detection from a 51-year-old male who underwent allogeneic hematopoietic stem cell transplantation. 
(1.1 and $1.2 \times 10^{3}$ copies $\left./ \mathrm{mL}\right)$ in each virus species, indicating that multiplex PCR certainly detects these viruses above copy numbers of $1 \times 10^{3} / \mathrm{mL}$ even with clinical specimens (Figure 2).

We then analyzed the median copy number on positive tests and false negative tests. As shown in Table 3, the median copy number on positive tests for $\mathrm{CMV}, \mathrm{JCV}$, and $\mathrm{BKV}$ ranged from $6.9 \times 10^{1}$ to $5.2 \times 10^{2}$ copies, indicating that multiplex PCR could detect these 3 virus species at low copy numbers. In contrast, the median copy numbers of HHV- 6 and ADV were $5.1 \times 10^{3}$ and $2.2 \times 10^{4}$ copies, respectively. These high median copy numbers were attributed to the presence of patients who had viremia with high copy numbers of HHV-6 or $\mathrm{ADV}$, and there were no false negative tests at copy numbers above $1 \times 10^{3} \mathrm{ex}$ cept for 2 tests in HHV-6 as mentioned above. The median copy numbers of false negative tests in CMV, JCV, BKV, HHV-6, ADV, and EBV ranged from 4.2 $\times 10^{1}$ to $1.3 \times 10^{2}$ copies, indicating that false negative results only occurred at low copy numbers of these viruses.

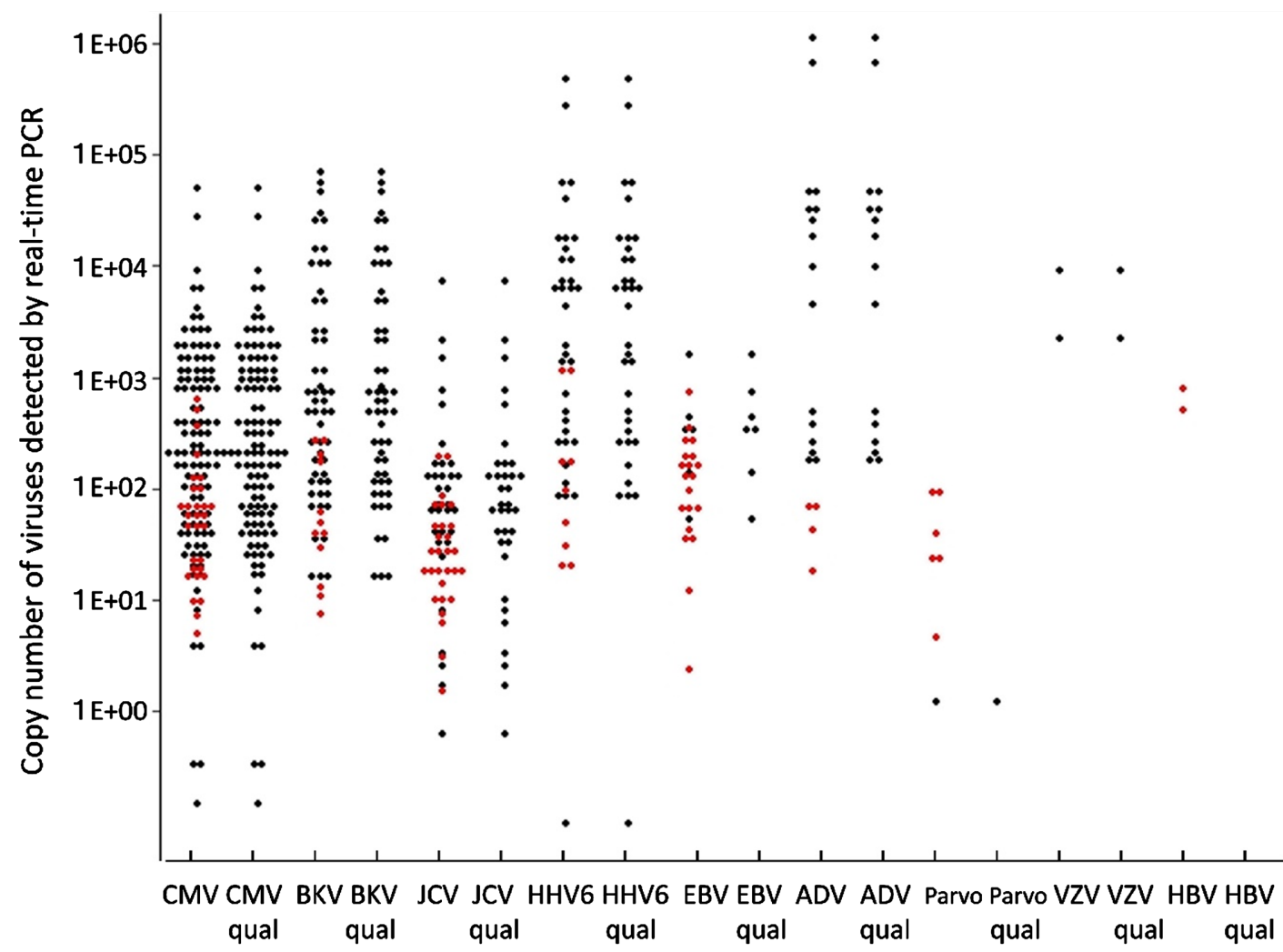

All real-time PCR positive results from 9 virus species are plotted alongside the results obtained by multiplex PCR (qual), showing the copy number of viruses and virus species on the vertical and horizontal axes, respectively. The presence of two horizontal plots means a true positive test (i.e. a positive test), while only one real-time PCR-positive plot means a false negative multiplex PCR test (in red color) at the indicated copy number. Data of HSV-1/2 and HHV-7/8 are not shown because of no virus detection in the present analysis. CMV: cytomegalovirus, BKV: BK virus, JCV: JC virus, HHV-6: human herpes virus type-6, EBV: Epstein-Barr virus, ADV: adenovirus, Parvo: parvovirus B19, VZV: varicella-zoster virus, HBV: human hepatitis B virus.

Figure 2. Relationship between positivity on real-time PCR and on multiplex qualitative PCR. 


\subsection{Frequency of False Positive and False Negative Tests with the Multiplex Virus PCR Assay}

As shown in Table 4, the frequency of false positive tests for CMV, JCV, BKV,

Table 3. Virus copy number in positive and false negative PCR tests.

\begin{tabular}{|c|c|c|}
\hline & $\begin{array}{l}\text { Copy number of positive tests (/mL blood) } \\
\text { (median \& range) }\end{array}$ & $\begin{array}{l}\text { Copy number of false negative tests (/mL blood) } \\
\text { (median \& range) }\end{array}$ \\
\hline \multirow{2}{*}{$\mathrm{CMV}$} & $2.0 \times 10^{2}$ copies $\left(3.5 \times 10^{-1}-5.0 \times 10^{4}\right)$ & $5.4 \times 10^{1}$ copies $\left(7.2 \times 10^{0}-6.2 \times 10^{2}\right)$ \\
\hline & $\mathrm{N}=112$ & $\mathrm{~N}=28$ \\
\hline \multirow{2}{*}{$\mathrm{JCV}$} & $6.9 \times 10^{1}$ copies $\left(1.7 \times 10^{0}-7.2 \times 10^{3}\right)$ & $2.7 \times 10^{1}$ copies $\left(1.7 \times 10^{1}-2.0 \times 10^{2}\right)$ \\
\hline & $\mathrm{N}=36$ & $\mathrm{~N}=25$ \\
\hline \multirow{2}{*}{$\mathrm{BKV}$} & $5.2 \times 10^{2}$ copies $\left(1.5 \times 10^{1}-6.9 \times 10^{4}\right)$ & $4.2 \times 10^{1}$ copies $\left(7.6 \times 10^{0}-2.9 \times 10^{2}\right)$ \\
\hline & $\mathrm{N}=55$ & $\mathrm{~N}=11$ \\
\hline \multirow{2}{*}{ HHV-6 } & $5.1 \times 10^{3}$ copies $\left(1.0 \times 10^{-1}-4.7 \times 10^{5}\right)$ & $7.3 \times 10^{1}$ copies $\left(1.9 \times 10^{1}-1.2 \times 10^{3}\right)$ \\
\hline & $\mathrm{N}=35$ & $\mathrm{~N}=8$ \\
\hline \multirow{2}{*}{$\mathrm{ADV}$} & $2.2 \times 10^{4}$ copies $\left(1.7 \times 10^{2}-1.1 \times 10^{6}\right)$ & $4.2 \times 10^{1}$ copies $\left(1.8 \times 10^{1}-7.0 \times 10^{1}\right)$ \\
\hline & $\mathrm{N}=16$ & $\mathrm{~N}=4$ \\
\hline \multirow{2}{*}{ EBV } & $3.4 \times 10^{2}$ copies $\left(5.2 \times 10^{1}-1.6 \times 10^{3}\right)$ & $1.3 \times 10^{2}$ copies $\left(2.4 \times 10^{0}-2.9 \times 10^{2}\right)$ \\
\hline & $\mathrm{N}=7$ & $\mathrm{~N}=20$ \\
\hline
\end{tabular}

Positive test: Positive result both in multiplex qualitative and quantitative PCR tests; false negative test: negative result in multiplex qualitative PCR but positive in quantitative PCR tests. NaN: not a number; namely, too small data for significant calculation.

Table 4. No, of positive, false positive, negative, and false negative tests and $\%$ of false positive and negative tests based of 421 qualitative-quantitative PCR tests.

\begin{tabular}{|c|c|c|c|c|c|c|}
\hline & $\begin{array}{l}\text { Positive } \\
\text { tests }\end{array}$ & $\begin{array}{c}\text { False } \\
\text { positive tests }\end{array}$ & $\begin{array}{c}\% \text { of false } \\
\text { positive tests }\end{array}$ & $\begin{array}{l}\text { Negative } \\
\text { tests }\end{array}$ & $\begin{array}{c}\text { False negative } \\
\text { tests }\end{array}$ & $\begin{array}{c}\% \text { of false } \\
\text { negative tests }\end{array}$ \\
\hline $\mathrm{CMV}$ & 112 & 8 & 6.7 & 273 & 28 & 9.3 \\
\hline JCV & 36 & 3 & 7.7 & 357 & 25 & 6.5 \\
\hline BKV & 55 & 4 & 6.8 & 351 & 11 & 3.0 \\
\hline HHV-6 & 35 & 5 & 12.5 & 373 & 8 & 2.1 \\
\hline $\mathrm{ADV}$ & 16 & 3 & 15.8 & 395 & 4 & 1.0 \\
\hline EBV & 7 & 2 & $(22.2)$ & 392 & 20 & 4.9 \\
\hline ParvoB19 & 1 & 0 & $(0)$ & 414 & 6 & 1.4 \\
\hline VZV & 2 & 3 & $(60.0)$ & 416 & 0 & (0) \\
\hline $\mathrm{HBV}$ & 0 & 0 & $(0)$ & 419 & 2 & $(0.5)$ \\
\hline HSV-1 & 0 & 0 & $(0)$ & 421 & 0 & (0) \\
\hline HSV-2 & 0 & 0 & $(0)$ & 421 & 0 & $(0)$ \\
\hline HHV-7 & 0 & 0 & (0) & 421 & 0 & (0) \\
\hline HHV-8 & 0 & 0 & (0) & 421 & 0 & (0) \\
\hline
\end{tabular}

Values in the parenthesis are results from the calculation based on very small data. CMV: cytomegalovirus, JCV: JC virus, BKV: BK virus, HHV-6/7/8: human herpes virus type-6/7/8, ADV: adenovirus, EBV: Epstein-Barr virus, ParvoB19: parvovirus B19, VZV: varicella-zoster virus, HBV: human hepatitis B virus, HSV-1/2: herpes simplex virus type-1/2. 
HHV-6, and ADV ranged from $6.7 \%$ to $15.8 \%$. The frequency of false negative tests was able to be evaluated in EBV in addition to these 5 viruses, ranging from $1.0 \%$ to $9.3 \%$.

\subsection{PPV, NPV, Sensitivity, and Specificity of the Multiplex Virus PCR Assay}

As shown in Table 5, the PPV and NPV in CMV, JCV, BKV, HHV-6, and ADV ranged from $84.2 \%$ to $93.3 \%$ and from $90.7 \%$ to $99.0 \%$, respectively. The NPV of EBV was $95.1 \%$. The sensitivity and specificity of CMV, JCV, BKV, HHV-6, and ADV ranged from $59.0 \%$ to $83.3 \%$ and from $97.2 \%$ to $99.2 \%$, respectively.

\section{Discussion}

In the present study, we evaluated whether or not the detection performance of our multiplex virus PCR assay with clinical specimens differed from that using synthesized virus plasmid DNA or preserved virus DNA, and observed equal performances of multiplex PCR assay in both evaluations in CMV, JCV, BKV, HHV -6, and ADV, which were frequently detected and thus reasonably analyzed (Table 1 and Table 3, Figure 2).

These 5 virus species are important to check for after HSCT, and we were able

Table 5. Positive and negative predictive values, sensitivity, and specificity based on 421 qualitative-quantitative PCR test.

\begin{tabular}{ccccc}
\hline & $\begin{array}{c}\text { Positive predictive } \\
\text { value (\%) }\end{array}$ & $\begin{array}{c}\text { Negative predictive } \\
\text { value (\%) }\end{array}$ & $\begin{array}{c}\text { Sensitivity } \\
(\%)\end{array}$ & $\begin{array}{c}\text { Specificity } \\
(\%)\end{array}$ \\
\hline CMV & 93.3 & 90.7 & 80.0 & 97.2 \\
JCV & 92.3 & 93.5 & 59.0 & 99.2 \\
BKV & 93.2 & 97.0 & 83.3 & 98.9 \\
HHV-6 & 87.5 & 97.9 & 81.4 & 98.7 \\
ADV & 84.2 & 99.0 & 80.0 & 99.2 \\
EBV & $(77.8)$ & 95.1 & $(25.9)$ & $(99.5)$ \\
ParvoB19 & $(100.0)$ & 98.6 & $(14.3)$ & $(100.0)$ \\
VZV & $(40.0)$ & $(100.0)$ & $(100.0)$ & $(99.3)$ \\
HBV & $(0)$ & 99.5 & $(0)$ & $(100.0)$ \\
HSV-1 & $(0)$ & $(100.0)$ & $(0)$ & $(100.0)$ \\
HSV-2 & $(0)$ & $(100.0)$ & $(0)$ & $(100.0)$ \\
HHV-7 & $(0)$ & $(100.0)$ & $(0)$ & $(100.0)$ \\
HHV-8 & $(0)$ & $(100.0)$ & $(0)$ & $(100.0)$ \\
\hline
\end{tabular}

Values in the parenthesis are results from the calculation based on very small data. CMV: cytomegalovirus, JCV: JC virus, BKV: BK virus, HHV-6/7/8: human herpes virus type-6/7/8, ADV: adenovirus, EBV: Epstein-Barr virus, ParvoB19: parvovirus B19, VZV: varicella-zoster virus, HBV: human hepatitis B virus, HSV-1/2: herpes simplex virus type-1/2. 
to reasonably calculate the PPV, NPV, sensitivity, and specificity of our multiplex PCR assay based on the results of real-time PCR as the reference. The PPV of these 5 viruses ranged from $84.2 \%$ (ADV) to 93.3\% (CMV) (Table 5), values that appeared satisfactory for routine clinical use. The number of false positive tests affects the PPV value. Although the reason for the false positive results with these five viruses (Table 4) is unclear, the results may be due to differences in regents used between multiplex PCR and real-time PCR. In the clinical laboratory, however, confirmation and quantification by real-time PCR is recommended when a positive result is obtained by multiplex virus PCR; therefore, the adverse effects of false positivity, including cross-reaction with unknown microorganisms, would be able to be avoided. In contrast, the NPV in the 5 viruses ranged $90.7 \%(\mathrm{CMV})$ to $99.0 \%$ (ADV) (Table 5), which was acceptable for routine laboratory use.

The sensitivity for these 5 viruses ranged from $59.0 \%$ (JCV) to $83.3 \%$ (BKV), showing rather low values (Table 5 ). Sensitivity is affected by the number of false negative test results; therefore, these values may have been attributable to the large number of false negative tests below the virus copy number of around 1 $\times 10^{2} / \mathrm{mL}$. Because the detection of viruses at these low copy numbers are not always needed in clinical practice, the sensitivity for these 5 viruses may be satisfactory after excluding false negative tests at low copy numbers. In contrast, the specificity of these 5 viruses ranged from 97.2\% (CMV) to $99.2 \%$ (JCV and ADV) (Table 5), which was acceptable in routine laboratory setting.

Generally, in PCR amplification reaction in the presence of multiple virus species, viruses with low amplicon size may be advantageous in the PCR detection. Although we did not perform the competition experiments, multiple virus detection at low copy number was frequently observed in the present study, which was typically shown in Figure 1 and Figure 2. Therefore, the competition between multiple viruses in our PCR amplification might be unlikely.

In the present study, the detection performance of multiplex PCR showed certain virus detection at more than $1.0 \times 10^{3}$ virus copies $/ \mathrm{mL}$ in analyses with clinical specimens. Regarding preemptive therapy for CMV infection after allogeneic HSCT, a study showed that three positive cells per two slides in a CMV antigenemia test (LSI Medience Corp., Tokyo, Japan) was a reasonable criterion for starting preemptive therapy for CMV disease in high-risk patients [22]. In our previous study using the same multiplex and real-time PCR assay system, 3 positive cells per two slides corresponded to $2.4 \times 10^{3} \mathrm{CMV}$ copies $/ \mathrm{mL}$ plasma [16]. Because our multiplex PCR assay definitely detects CMV genome/DNA at more than $1 \times 10^{3}$ copies $/ \mathrm{mL}$, delay in CMV preemptive treatment due to false negative result would be unlikely. Indeed, in the present study and previous study [16], none of patients developed life-threatening CMV disease because of early treatment with gancyclovir based on regular virus check with the multiplex PCR.

HHV-6 is also important and should be frequently monitored in HSCT patients because it rapidly proliferates and often causes encephalitis when its blood 
load is high [23]. Ogata et al. reported that more than $1 \times 10^{4}$ HHV-6 DNA copies/mL plasma was the threshold value causing encephalitis using an ABI PRISM 7700 Sequence Detection System (Applied Biosystems, Tokyo, Japan) [24]. Our multiplex PCR assay can detect HHV-6 DNA at $\geq 1 \times 10^{3} /$ copies $\mathrm{mL}$ plasma with certainty; therefore, delay in HHV-6 preemptive treatment due to false negative test would also be unlikely. In fact, none of patients developed critical HHV-6 encephalitis in our institution because of frequent HHV-6 monitoring with the multiplex PCR and early treatment with foscavir. In another study, Inazawa et al. described 2 patients who developed HHV-6 encephalitis at a minimum blood viral load of around $3.8 \times 10^{3}$ copies $/ \mu \mathrm{g}$ DNA $\left(=10^{4}\right.$ copies $/ 1 \mathrm{~mL}$ blood $)$ using the same virus PCR system as us [25]. Of note, a standardized real-time PCR assay system has not yet been established [26]. In relation to multicenter comparison of real-time PCR assay system [26], our real-time PCR is similar to the PCR assays $1,2,4$, and 6 shown in the study, and our measuring value is also similar to those of these 4 PCR systems.

Regarding time performance of our multiplex PCR assay, simultaneous screening of 13 virus species within $3 \mathrm{~h}$ may be superior to single-virus real-time PCR to detect viruses possibly involved in unknown infection or inflammation. Blood PCR analysis also appears to be enough to predict organ viral infection as previously described [16].

As for the cost of our multiplex PCR assay, one multiplex qualitative PCR assay for 13 viruses costs about $\$ 131$ US. When one virus is detected, one real-time PCR assay is performed to determine the viral load, coming to a cost of \$34 US. Therefore, our multiplex PCR assay shows reasonable cost performance as a routine clinical laboratory test. In addition, this confirmation and viral load determination by real-time PCR takes about 45 min, leading to early intervention of anti-viral treatment if needed.

The limitations associated with the present study include the rather small number of HSC-transplanted patients included; small number of positive tests for JCV, HHV-6, and ADV; and few or no virus detection of EBV, ParvoB19, VZV, HVB, HSV-1/2, and HHV-7/8. Regarding these limitations, we previously examined viremia in another cohort of HSC-transplanted patients using a similar multiplex PCR assay system that detects all the same virus species except for ADV [16], and the virus detection performance was nearly the same as in the present study. With this background, the first two limitations may not be major weak points of this study. However, continued improvement of the ADV detection performance is required. Regarding the third limitation, however, it would be difficult to obtain an appropriate number of positive tests to conduct reasonable analyses, as even in our previous patient cohort, which contained more high-risk patients [16], positivity for these eight viruses was only sporadic.

\section{Conclusion}

Our multiplex qualitative virus PCR assay for 13 virus species may be suitable 
for clinical laboratory use in terms of its sensitivity, specificity, reproducibility, and time and cost performance.

\section{Funding}

This work was supported in part by the International Supportive Society for Patients Receiving Cord Blood Transplantation, and Donations of Scholarships by Astellas Pharma Inc. (Tokyo, Japan) and CHUGAI Pharm Co., LTD. (Tokyo, Japan). Neither was involved in the study design, data collection, analysis, or interpretation of the data.

\section{Acknowledgements}

The authors are grateful to Miss Mizue Higashi, Mrs. Yuko Uemura, and Miss Miho Shibata for their excellent support in the manuscript preparation and literature search, the statistical analyses and data evaluation, and the figure drawing, respectively.

\section{Conflicts of Interest}

The authors declare no conflicts of interest regarding the publication of this paper.

\section{References}

[1] Klemola, E., Von Essen, R., Henle, G. and Henle, W. (1970) Infectious-MononucleosisLike Disease with Negative Heterophil Agglutination Test. Clinical Features in Relation to Epstein-Barr Virus and cytomegalovirus Antibodies. The Journal of Infectious Diseases, 121, 608-614. https://doi.org/10.1093/infdis/121.6.608

[2] Lang, D., Vornhagen, R., Rothe, M., Hinderer, W., Sonneborn, H.H. and Plachter, B. (2001) Cross-Reactivity of Epstein-Barr Virus-Specific Immunoglobulin M Antibodies with Cytomegalovirus Antigens Containing Glycine Homopolymers. Clinical and Diagnostic Laboratory Immunology, 8, 747-756. https://doi.org/10.1128/CDLI.8.4.747-756.2001

[3] Wakefield, A.J., Fox, J., Sawyerr, A.M., Taylor, J.E., Sweenie, C.H., Smith, M., Emery, V.C., Hudson, M., Tedder, R.S. and Pounder, R.E. (1992) Detection of Herpesvirus DNA in the Large Intestine of Patients with Ulcerative Colitis and Crohn's Disease Using the Nested Polymerase Chain Reaction. Journal of Medical Virology, 38, 183-190. https://doi.org/10.1002/jmv.1890380306

[4] Hirsch, H.H., Knowles, W., Dickenmann, M., Passweg, J., Klimkait, T., Mihatsch, M.J. and Steiger, J. (2002) Prospective Study of Polyomavirus Type BK Replication and Nephropathy in Renal-Transplant Recipients. The New England Journal of Medicine, 347, 488-496. https://doi.org/10.1056/NEJMoa020439

[5] Behzad-Behbahani, A., Klapper, P.E., Vallely, P.J., Cleator, G.M. and Bonington, A. (2003) BKV-DNA and JCV-DNA in CSF of Patients with Suspected Meningitis or Encephalitis. Infection, 31, 374-378. https://doi.org/10.1007/s15010-003-3078-5

[6] Kalpoe, J.S., van der Heiden, P.L., Barge, R.M., Houtzager, S., Lankester, A.C., van Tol, M.J. and Kroes, A.C. (2007) Assessment of Disseminated Adenovirus Infections Using Quantitative Plasma PCR in Adult Allogeneic Stem Cell Transplant Recipients Receiving Reduced Intensity or Myeloablative Conditioning. European 
Journal of Haematology, 78, 314-321.

https://doi.org/10.1111/j.1600-0609.2007.00821.x

[7] Hirsch, H.H., Lautenschlager, I., Pinsky, B.A., Cardeñoso, L., Aslam, S., Cobb, B., Vilchez, R.A. and Valsamakis, A. (2013) An International Multicenter Performance Analysis of Cytomegalovirus Load Tests. Clinical Infectious Diseases, 56, 367-373. https://doi.org/10.1093/cid/cis900

[8] Khare, R., Espy, M.J., Mandrekar, J.N. and Binnicker, M.J. (2014) Comparison of a Transplant Multiplex Viral Panel on the ICEPlex System with Real-Time PCR for Detection of Cytomegalovirus, Epstein-Barr Virus, and BK Virus in Clinical Specimens. Journal of Clinical Microbiology, 52, 1711-1713.

https://doi.org/10.1128/JCM.00358-14

[9] Ma, X., Xu, H., Shi, L., Yang, P., Zhang, L., Sun, X., Zhen, W. and Hu, K. (2015) A Multiplex PCR Assay for the Detection of Five Influenza Viruses Using a Dual Priming Oligonucleotide System. BMC Infectious Diseases, 15, Article No. 93. https://doi.org/10.1186/s12879-015-0818-y

[10] Wang, Y., Zhu, S., Hong, W., Wang, A. and Zuo, W. (2017) A Multiplex PCR for Detection of Six Viruses in Ducks. The Journal of Virological Methods, 248, 172-176. https://doi.org/10.1016/j.jviromet.2017.07.004

[11] Huang, H.S., Tsai, C.L., Chang, J., Hsu, T.C., Lin, S. and Lee, C.C. (2018) Multiplex PCR System for the Rapid Diagnosis of Respiratory Virus Infection: Systematic Review and Meta-Analysis. Clinical Microbiology and Infection, 24, 1055-1063. https://doi.org/10.1016/j.cmi.2017.11.018

[12] Guo, X., Wang, S., Zhao, C., Li, J.W. and Zhong, J.Y. (2018) An Integrated Cell Absorption Process and Quantitative PCR Assay for the Detection of the Infectious Virus in Water. Science of the Total Environment, 635, 964-971. https://doi.org/10.1016/j.scitotenv.2018.04.223

[13] Liu, P., Lu, L., Xu, M., Zhong, H., Jia, R., Su, L., Cao, L., Dong, Z., Dong, N., Zhou, L. and Xu, J. (2018) A Novel Multiplex PCR for Virus Detection by Melting Curve Analysis. The Journal of Virological Methods, 262, 56-60.

https://doi.org/10.1016/j.jviromet.2018.09.010

[14] Hwang, K.A., Ahn, J.H. and Nam, J.H. (2018) Development and Validation of Multiplex Real-Time PCR Assays for Rapid Detection of Cytomegalovirus, Epstein-Barr Virus, and Polyomavirus BK in Whole Blood from Transplant Candidates. Journal of Microbiology, 56, 593-599. https://doi.org/10.1007/s12275-018-8273-2

[15] Ito, K., Shimizu, N., Watanabe, K., Saito, T., Yoshioka, Y., Sakane, E., Tsunemine, H., Akasaka, H., Kodaka, T. and Takahashi, T. (2013) Analysis of Viral Infection by Multiplex Polymerase Chain Reaction Assays in Patients with Liver Dysfunction. Internal Medicine, 52, 201-211. https://doi.org/10.2169/internalmedicine.52.8206

[16] Tsunemine, H., Yoshioka, Y., Nagao, M., Tomaru, T., Saitoh, T., Adachi, S., Shimizu, N. and Takahashi, T. (2016) Multiplex Polymerase Chain Reaction Assay for Early Diagnosis of Viral Infection. IntechOpen, London.

https://doi.org/10.5772/65771

[17] Nagao, M., Yoshioka, Y., Saito, T., Tsunemine, H., Ito, K., Kodaka, T., Tsuji, G., Watanabe, K., Shimizu, N. and Takahashi, T. (2017) Six Cases of Infectious Mononucleosis by Cytomegalovirus as Diagnosed by Multiplex Virus PCR Assay. Journal of Blood and Lymph, 7, 165.

[18] Sasaki, M., Shimizu, N., Zushi, Y., Saito, T., Tsunemine, H., Itoh, K., Aoyama, Y., Goto, Y., Kodaka, T., Tsuji, G., Senda, E., Fujimori, T., Itoh, T. and Takahashi, T. (2018) Analysis of Gastrointestinal Virus Infection in Immunocompromised Hosts 
by Multiplex Virus PCR Assay. AIMS Microbiology, 4, 225-239. https://doi.org/10.3934/microbiol.2018.2.225

[19] Inazawa, N., Hori, T., Hatakeyama, N., Yamamoto, M., Yoto, Y., Nojima, M., Suzuki, N., Shimizu, N. and Tsutsumi, H. (2015) Large-Scale Multiplex Polymerase Chain Reaction Assay for Diagnosis of Viral Reactivations after Allogeneic Hematopoietic Stem Cell Transplantation. Journal of Medical Virology, 87, 1427-1435. https://doi.org/10.1002/jmv.24161

[20] Nakano, S., Sugita, S., Tomaru, Y., Hono, A., Nakamuro, T., Kubota, T., Takase, H., Mochizuki, M., Takahashi, M. and Shimizu, N. (2017) Establishment of Multiplex Solid-Phase Strip PCR Test for Detection of 24 Ocular Infectious Disease Pathogens. Investigative Ophthalmology \& Visual Science, 58, 1553-1559. https://doi.org/10.1167/iovs.16-20556

[21] Jones, S., Webb, E.M., Barry, C.P., Choi, W.S., Abravaya, K.B., Schneider, G.J. and Ho, S.Y. (2016) Commutability of Cytomegalovirus WHO International Standard in Different Matrices. Journal of Clinical Microbiology, 54, 1512-1519. https://doi.org/10.1128/JCM.03292-15

[22] Kanda, Y., Yamashita, T., Mori, T., Ito, T., Tajika, K., Mori, S., Sakura, T., Hara, M., Mitani, K., Kurokawa, M., Akashi, K. and Harada, M. (2010) A Randomized Controlled Trial of Plasma Real-Time PCR and Antigenemia Assay for Monitoring CMV Infection after Unrelated BMT. Bone Marrow Transplantation, 45, 1325-1332. https://doi.org/10.1038/bmt.2009.337

[23] Ogata, M., Kikuchi, H., Satou, T., Kawano, R., Ikewaki, J., Kohno, K., Kashima, K., Ohtsuka, E. and Kadota, J. (2006) Human Herpesvirus 6 DNA in Plasma after Allogeneic Stem Cell Transplantation: Incidence and Clinical Significance. The Journal of Infectious Diseases, 193, 68-79. https://doi.org/10.1086/498531

[24] Ogata, M., Satou, T., Kadota, J., Saito, N., Yoshida, T., Okumura, H., Ueki, T., Nagafuji, K., Kako, S., Uoshima, N., Tsudo, M., Itamura, H. and Fukuda, T. (2013) Human Herpesvirus 6 (HHV-6) Reactivation and HHV-6 Encephalitis after Allogeneic Hematopoietic Cell Transplantation: A Multicenter, Prospective Study. Clinical Infectious Diseases, 57, 671-681. https://doi.org/10.1093/cid/cit358

[25] Inazawa, N., Hori, T., Yamamoto, M., Hatakeyama, N., Yoto, Y., Nojima, M., Yasui, H., Suzuki, N., Shimizu, N. and Tsutsumi, H. (2016) HHV-6 Encephalitis May Complicate the Early Phase after Allogeneic Hematopoietic Stem Cell Transplantation: Detection by Qualitative Multiplex PCR and Subsequent Quantitative RealTime PCR. Journal of Medical Virology, 88, 319-323. https://doi.org/10.1002/jmv.24340

[26] Flamand, L., Gravel, A., Boutolleau, D., Alvarez-Lafuente, R., Jacobson, S., Malnati, M.S., Kohn, D., Tang, Y.W., Yoshikawa, T. and Ablashi, D. (2008) Multicenter Comparison of PCR Assays for Detection of Human Herpesvirus 6 DNA in Serum. Journal of Clinical Microbiology, 46, 2700-2706. https://doi.org/10.1128/JCM.00370-08 